\title{
A TÉR ÉS TÁRSADALOM ELSŐ HÚSZ ÉVE
}

\author{
(The First 20 Years of Space and Society)
}

\section{RECHNITZER JÁNOS}

\section{Elsóként a tényekról}

A Tér és Társadalom húsz évfolyama alatt 64 folyóirat szám jelent meg. A közel 11 ezer nyomtatott oldalt 882 szerzö írta, ebböl 70 fö volt külföldi, akik 65 cikket, tanulmányt adtak közre. A megjelent 614 tanulmánynak több mint a fele elméleti jellegü volt, a többi a folyóirat megalakulásától alapvetöen követett tematikus rovatokhoz kapcsolódott. A Krónika, majd Könyvjelzỏ rovatban 178 könyv, tanulmánykötet ismertetése jelent meg.

A szerkesztőbizottság elnöke az alapítás óta (1987) Enyedi György, a tagok nagy aktivitással változtak, döntően az MTA Regionális Kutatások Központja egységeinek vezető kutatóiból tevődtek össze.

Alapító föszerkesztő: Tóth József, alapító szerkesztőként regisztrálhatjuk: Barta Györgyit és Hajdú Zoltánt, 11 szám összeállítását végezték el, utolsó, általuk gondozott szám az 1989. 3. volt.

Beluszky Pál az 1989. 4. számtól vette át a folyóirat föszerkesztői feladatait, munkáját segítették szerkesztőként: Daróczi Etelka, Zentai Viktória, Dúró Annamária, Tímár Lajos, Váradi Mónika Mária (az 1991. 4. számig), Mészáros Júlia (az 1992. 1-2. számtól az 1992. 3. számig felelős szerkesztőként), az utolsó szám (az 1993. 1-2.) Tímár Judit és Zentai Violetta segítségével került összeállitásra.

Az 1993-ban kapott felkérés alapjản az 1993. 3-4. számtól jegyzem föszerkesztőként a folyóiratot. Felelös szerkesztő volt Pfeil Edit az 1995. 3-4. számig, az 1996. 1. szám összeállítását Telekes Annamária segítette, majd felelös szerkesztőként 1996. 2-3. számtól 1998. 1-2. számig Nagy Erikával dolgoztunk együtt. 1998. 3. számtól napjainkig Nárai Márta és Hardi Tamás a Tér és Társadalom felelős szerkesztöje. A technikai szerkesztés feladatait 1996. 2-3. számtól kezdődően Kömüves Mária látja el.

A három föszerkesztỏi időszakban más és más szemléletben történt a lap szerkesztése. Az első idöszakban még nem voltak tematikus számok, ekkor alakultak ki a későbbi rovatok, nagy figyelmet kapott, hogy minden számban egy-egy, a regionális tudomány neves külföldi szaktekintélyének magyar nyelvre fordított cikke jelenjen meg.

A Beluszky Pál által szerkesztett tíz számból hat tematikus volt, így foglalkoztak a társadalom térhódításával, a mikroterekkel, a választási földrajzzal, a területi politikával, Budapesttel és a nök szerepével a térben, társdalomban. Ezekben, a számokban jelentek meg elsöként fényképek illusztrációként, nagy számban adtak közre külföldi szerzöket (23 fó) és kitekintésként külföldi összehasonlító tanulmányokat (20 egység). 
A Tér és Társadalom az MTA IX. osztálya (Jog- és Gazdaságtudományi Osztály), valamint az MTA Regionális Kutatások Központja negyedéves folyóirata. A kiadás költsége éves átlagban 2-2,3 millió Ft, aminek többségét 70-75\%-át az RKK a kutatási költségeiböl fedezi, az MTA támogatás 20-25\%-ot tesz ki, csökkenó mértékben, s 3-5\% között van az elöfizetöi, illetve az eladott példányszámok utáni bevétel. A Tér és Társadalom egyes számai 500 példányban jelennek meg, ebböl napi állás szerint - 163 intézményi és 90 egyéni előfizetővel rendelkezünk. Az előfizetők száma stabilnak mondható, az évek alatt inkább csökkent az intézményi kör szervezeti összevonások, takarékosság -, ugyanakkor az egyéni előfizetők száma emelkedett, s a kettő együtt stabil vagy kis mértékủ növekedést mutat. A fenn maradó példányok az RKK cserekapcsolataira, szerzői tiszteletpéldányokra fordítódnak. A folyóiratot három évben (2002-2004) támogatta a Nemzeti Kulturális Alapprogram, mely forrást szerzöi és fordítói honoráriumokra, kis részben nyomdai költségekre fordítottunk, valamint az Interneten történő megjelenés finnanszírozásához járult hozzá az Alapprogram. Ugyanakkor a lap nem ad helyet reklámnak. Jelenleg a Tér és Társadalom nem fizet a szerzőknek, s nem kér megjelentetési hozzájárulást.

A folyóirat szerkesztése 1994-től Győrben zajlik, az MTA RKK Nyugatmagyarországi Tudományos Intézet gondozásában Hardi Tamás és Nárai Márta a felelös szerkesztő. A terjesztés szintén Györből történik. A Tér és Társadalom 1996. 1. számtól olvasható az interneten (www.rkk.hu), egy évfolyam késéssel kerülnek fel a füzetek a honlapra. A folyóirat régebbi számaiból néhány példány még megtalálható az RKK könyvtárában, illetve a Nyugat-magyarországi Tudományos Intézetben, így igény szerint a hiảnyzók beszerezhetök.

\section{A szerzök és hálózatok}

A Tér és Társadalom szerzői körének és szakmai kapcsolatainak elemzése a hazai regionális tudomány kistükre. Megvizsgáltuk, hogy a 882 szerzőt milyen szakmai csoportokba sorolhatjuk be, vagyis azt kutattuk, hogy a regionális tudomány elméleti folyóiratában milyen végzettségủ - magukat mely szakmához soroló - szerzők milyen arányban publikálnak (1. ábra).

Az 1. ábra a feldolgozott 20 évfolyam szerzöinek szakmai képzettség szerinti öszszetételét villantja fel. A geográfus, földrajzos végzettségủ szakemberek adják a szerzők 37,5\%-át, részesedésük a publikációkban a feldolgozott évfolyamok során egyenletesen magas volt, de látványos aktivitást az ezredfordulótól mutattak. A közgazdászok következnek a sorban 29,6\%-kal. Jellemző erre a szakmacsoportra, hogy az alakulás éveiben a szerzők kisebb hányada tartozott ide, majd aktivitásuk a kilencvenes évek közepétỏl emelkedett, s szintén az ezredforduló után ugrott meg. A sorrendet a szociológusok követik, 10,2\%-kal, s az ezredfordulótól egyre nagyobb számban publikálnak a folyóiratban. A történész végzettségủ szerzők inkább az indulás éveiben, majd a kilencvenes évek első harmadában jelentkeznek a lapnál. A jogászok publikációs aktivitása visszafogott, hiszen csupán 3,2\%-ot képviselnek 
a szerzöi körbő̉l, ami aránytalanul mérsékelt a regionális tudományban elfoglalt helyükhöz - s mondhatni befolyásukhoz - mérten. Hasonlóan visszafogott, szinte említésre sem méltó a politológusok $(2,1 \%)$ és az építészek $(1,7 \%)$ publikációs jelenléte. Az egyéb kategóriába soroltuk a néprajzos, a mérnök (település, müszaki), az agrár, a környezettudományi, a biológus, hidrológus, a szociális munkás, a tanár végezettséggel bíró szerzőinket, illetve akiknél nem tudtuk megállapítani a szakmai kötődést, ez vonatkozott számos külföldi szerzőre.

\section{1. ÁBRA}

A Tér ês Társadalom szerzöi szakterület szerint (1997-2006)

(Authors of Space and Society According to Their Specialization (1997-2006)

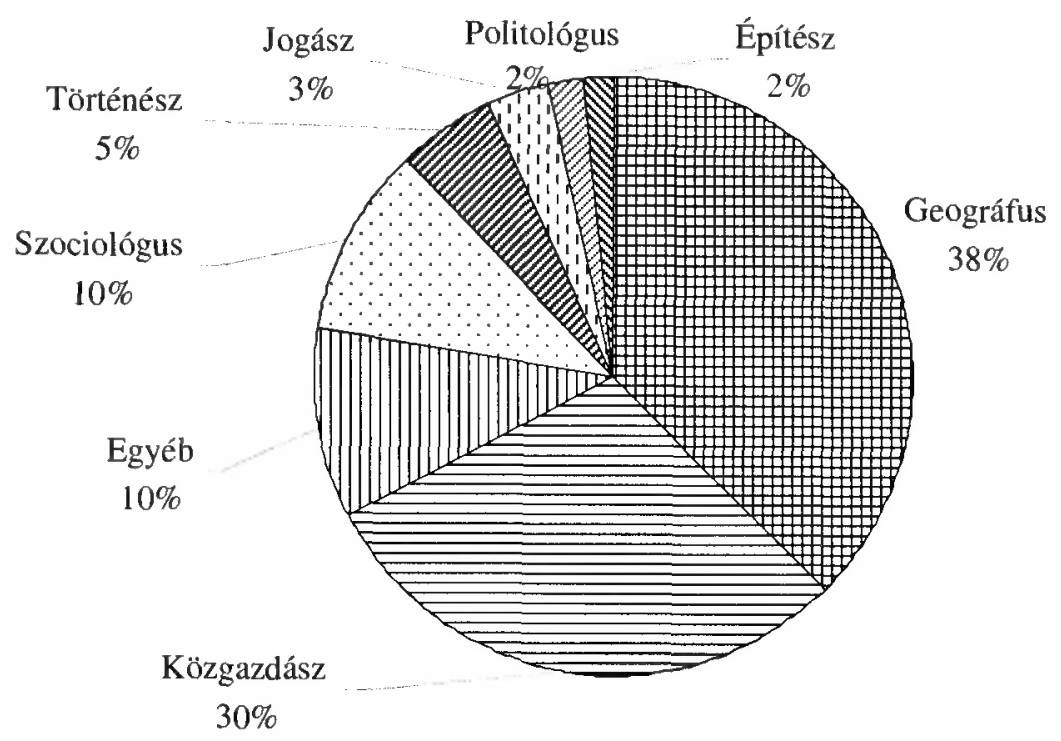

Forrás: A Tér és Társadalom számai, 1987-2006, saját gyüjtés.

A folyóirat szerzöinek feldolgozása azt mutatja, hogy a regionális tudomány szélesedő szakmai bázist épít ki, az alkotó diszciplínák (földrajz, közgazdaságtan) mellett egyre élénkebb a területi társadalmi jelenségek iránti érdeklődés, így látványos például a szociológiát múvelő szakemberek publikációs aktivitása. A területi folyamatok által érintett témák szintén bővülnek, s ennek köszönhetô, hogy egyre több szakma dolgozza fel eredményeit tudományos publikációkba, amiknek közreadásában a Tér és Társadalom mindig nyitott volt és lesz a jövőben is.

A Tér és Társadalom folyóirat elemzését folytatva tekintsük át a publikáló szerzők intézményi hova tartozását (1. táblázat). 1987 és 2005 között a legtöbbet publikáló 15 szerző közül 12 kutatóként dolgozott és dolgozik ma is az MTA Regionális Kutatások Központja valamelyik egységénél. 
1. TÁBLÁZAT

A Tér és Társadalom legtöbbet publikáló szerzői munkahely szerint (1987-2005) (Authors of Space and Society Publishing the Most, According to Work Place (1987-2005)

\begin{tabular}{lcc}
\hline \multicolumn{1}{c}{ Név } & Önálló publikálás & Összes publikálás \\
\hline Rechnitzer János (NYUTI) & 11 & $11+2$ (párban) \\
Erdösi Ferenc (DTI) & 10 & 10 \\
Faragó László (DTI) & 10 & $10+1$ (párban) \\
Horváth Gyula (DTI) & 8 & $8+1$ (párban) \\
Szörényiné Kukorelli Irén (NYUTI) & 6 & 6 \\
Barta Györgyi (KÉTI) & 5 & 5 \\
Döry Tibor (NYUTI) & 5 & 5 \\
Hajdú Zoltán (DTI) & 5 & 5 \\
Kovács Teréz (DTI) & 5 & 5 \\
Bartke István (ELTE) & 4 & 4 \\
Beluszky Pál (KÉTI) & 4 & $4+2$ (párban) \\
Enyedi György (MTA) & 4 & $4+1$ (párban) \\
Lados Mihály (NYUTI) & 4 & $4+1$ (párban) \\
Nagy Gábor (NYUTI) & 4 & 4 \\
Nemes Nagy József (ELTE) & 4 & $4+1$ (párban) \\
\hline
\end{tabular}

Forrás: A Tér és Társadalom alapján a szerzők feldolgozása.

Kísérletet tettünk arra, hogy a Tér és Társadalom évfolyamainak feldolgozásával feltárjuk a regionális tudomány szakmai, kutatói hálózatát, ami szerzők egymás közötti hivatkozásának feldolgozásával történt meg. A kutatói hálózatokra vonatkozó elemzés során az összegyűjtött adatok nagy hányada a hálózatkutatás szempontjából nem volt használható, hiszen a hivatkozottak többsége nem publikált a folyóiratban, így a viszonthivatkozás sem történhetett meg. Ki kellett vennünk továbbá az adatbázisból az összes külföldi szerzöt és a lapban nem publikáló magyar szerzőket is ${ }^{2}$. A többszerzős cikkek esetében a szerzöket külön-külön jelenítettük meg, az adott cikk hivatkozásait mindegyik személy esetében feltüntetve.

Az elemzésben 179 szerzővel készült el az adatmátrix, ami alapján elöállítható a hivatkozási háló. Amennyiben további, a diszciplínához kapcsolható magyar folyóiratok is az elemzésbe kerülnek, úgy még teljesebb kép alakítható ki a regionális tudomány színtereiröl.

A vizsgálatba ${ }^{3}$ bevont szerzőknél még két tényezöt gyüjtöttünk ki. Elsőként a szakképzettséget, amivel a szerzök tudományterületét határozhattuk meg, másodikként az intézményi hovatartozást, és ezen tényezővel még a regionális tudomány térbeli elhelyezkedését is jellemezhettük. A mobilitás - sem a területi, sem az intézményi - nem jellemzi a hazai tudományos életet, azoknál a többcikkes szerzőknél, ahol ilyet mégis tapasztaltunk (pl. legtöbb esetben a doktori iskola elvégzése utáni új munkahely jelenti a változást) ott a legutolsó cikknél megjelölt intézményt vettuik alapul, a diszciplínák váltásánál hasonlóképpen jártunk el. 
A regionális tudomány meglehetősen fiatal diszciplína (1984-tỏl intézményesült, illetve 1988-ban történt a befogadása a Magyar Tudományos Akadémiába) ezért joggal merülhet fel a kérdés, hogy kik azok a személyek, akik a legnagyobb hatással voltak a tudományág magyarországi kialakulására.

A Tér és Társadalomra végzett hálózatelemzés több sajátosságot mutat. Mivel kihúztunk minden olyan személyt, akiktöl nem indul hivatkozás (nem hivatkoztak senkire), vagy kizárólag csak hivatkozásban szerepeltek, egy meglehetősen zárt hálózat jött létre. További érdekessége a hivatkozási hálóknak, hogy nagyban torzítja az adatokat a körbe- és a visszahivatkozás, ami szintén a regionális tudomány zártságából következik ${ }^{4}$. A tudományos pályán eltöltött évek száma szintén meghatározó lehet a hálózatban elfoglalt hely szempontjából. S végül a hálózati pozíciót befolyásolhatja a közlemények, egyben a kutatási területek speciális volta. Elöfordulnak olyan egyedülálló témák, amelyek csak egy kis csoport érdeklődésére - s ezzel együtt hivatkozására - számíthatnak.

A Tér és Társadalom szerzöi hálózatának zártságát az is alátámasztja, hogy a vizsgálatba bevont cikkek $86 \%$-át az MTA RKK valamelyik kutatóintézetének munkatársa írta. A mátrixban szereplő szerzöknek viszont $34 \%$-a volt az intézeti hálózat munkatársa. Mivel a folyóirat az MTA RKK gondozásában jelenik meg ez a tény egyáltalán nem meglepő.

A hálózatban a lehetséges kapcsolatok száma 32041 (önhivatkozásokat is beleszámolva), a tényleges kapcsolatok száma 895, ebböl 94 önhivatkozás. Az adatbázist a vizsgálathoz dichotomizáltuk, tehát az elöbbi adat azt jelenti, hogy az összes szerzö közül 94-en hivatkoztak saját magukra. A továbbiakban, amennyiben azt nem jelezzük, az önhivatkozásokat is belevettük a vizsgálatba.

Az hálózat sürúsége 0,028 , vagyis a lehetséges kapcsolatoknak a 2,8\%-a létezik a valóságban. A szórás 0,165 , ami majdnem hatszorosa a sủrüségnek, vagyis a hivatkozások eloszlása korántsem egyenletes. Ez sem meglepö, hiszen a tudományos hierarchia összes szintje képviselteti magát a szerzők között a PhD hallgatótól az MTA rendes tagjáig, ahol az alacsonyabb fokozatú, a tudományos nyilvánosságban kevesebb ideje tevékenykedö, nagyoì horderejü mủvekkel még nem rendelkezö szerzők eleve kisebb eséllyel indulnak a hivatkozásokért folytatott küzdelemben.

Elsőként az egyes szerzőktöl kifutó és a hivatkozottakhoz befutó hivatkozások tényleges és az elméletileg lehetséges mennyiségének arányát vizsgáltuk, amellyel a hálózat általános sủrüségi mutatója tovább finomítható. Az egyes szerzőktől kiinduló hivatkozások (kifok) alapján számított sürüségek közül a legnagyobb $15,6 \%$ (tehát volt olyan szerző, aki az adatbázisban szereplö szerzök egyhatodára hivatkozott. Amennyiben az egyes szerzökre történt hivatkozásokból indulunk ki (befok), akkor itt a legnagyobb sủrüség $35,2 \%$. Vagyis volt olyan szerzö, akire a TéT szerzöinek több mint egyharmada hivatkozott. Az adatbázisban szereplö 179 szerzőből 34 fö nem kapott hivatkozást, csak ő hivatkozott, míg 22 fő nem hivatkozott a 179 szerző egyikére sem. A legnagyobb kifok sürüséggel rendelkezök között értelemszerủen azok találhatóak, akiknek több esélye volt a megnyilatkozásra a lap hasábjain, azaz akik többet publikáltak. A folyóiratra, ezzel magára a tudományos közösségre legnagyobb hatással lévő személyeket a legsủrúbb, legmagasabb befokkal rendelkezö szerzők között kell keresnünk. Összesen hat szerzö (Enyedi György, Horváth Gyula, 
Rechnitzer János, Beluszky Pál, Lengyel Imre, Nemes Nagy József), kutató van a hálózatban, akiknél a befok szerinti sürüség nagyobb, mint 10\%. Ezen szerzők közül három (Rechnitzer János, Horváth Gyula és Lengyel Imre) hasonlóan magas kifok szerinti sủrủséggel rendelkezik, azaz a meghatározó helyet foglalnak el a hálózatban és a regionális tudomány szakmai nyilvánosságában.

Amennyiben a fókomponens elemzést hajtunk végre az adatbázison, akkor a legtöbbet hivatkozott szerzök kerülnek az egyes fökomponensek élére. Ha összevetjük a 2. ábrát az 1. táblázattal, láthatjuk, hogy nem feltétlenül igaz az a megállapítás, hogy a Tér és Társadalomban legtöbbet publikálók a legmeghatározóbb szakmai személyiségek a regionális tudomány szempontjából.

\section{2. ÁBRA}

A Tér és Társadalom hivatkozási hálója fökomponens elemzés alapján (Citation Network of Space and Society According to Main Component Analysis)

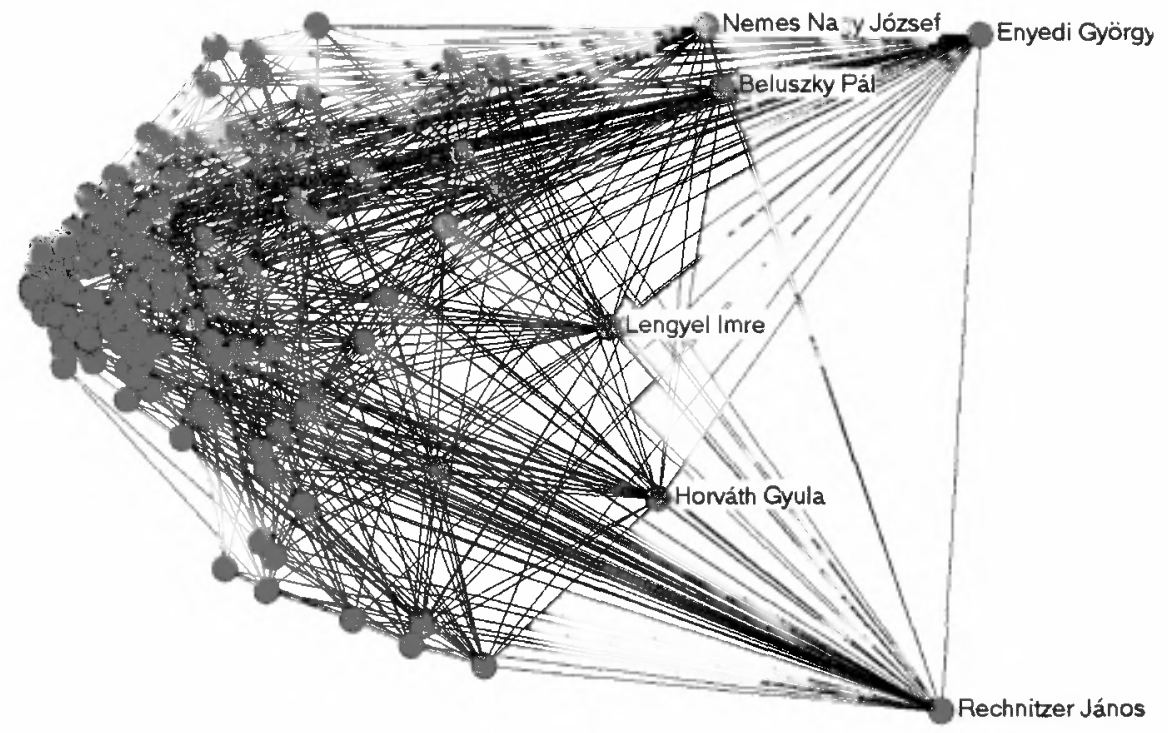

Forrás: Sajắt szerkesztés.

Az elsö két fökomponensben Enyedi György és Rechnitzer János találhatóak. Enyedi György - akit a magyar regionális tudomány atyjaként tart számon a szakma rendelkezik a legtöbb befelé irányuló kapcsolattal, munkássága meghatározó a diszciplína szempontjából. Érdekes módon az adatbázisban található 179 szerzỏre nem jutott olyan sok Enyedi György hivatkozásaiból, amit a saját 5,6\%-os kifok sürủsége is jelez. Ez a tény Enyedi György szakmai múltjából és a regionális tudományban elfoglalt központi helyéból fakad. ${ }^{5}$ A továbbiakban három, a regionális tudomány iránt elkötelezett kutató következik: Horváth Gyula (MTA RKK főigazgató, egyetemi tanár) és Nemes Nagy József (ELTE TTK Regionális Földrajzi Tanszék, egyetemi tanár) és Lengyel Imre (SZTE Alkalmazott Közgazdaságtan Tanszék, egyetemi tanár), s a hazai társadalomföldrajz nagy ,öregje" Beluszky Pál (MTA RKK KÉTI tudományos tanácsadó). 
Rechnitzer János : A Tér és Társadalom első húsz éve

Tér és Társadalom 20. évf. 2006/4. 1-13. p.

TÉT XX. évf. 2006 - 4

A Tér és Társadalom elsö húsz éve

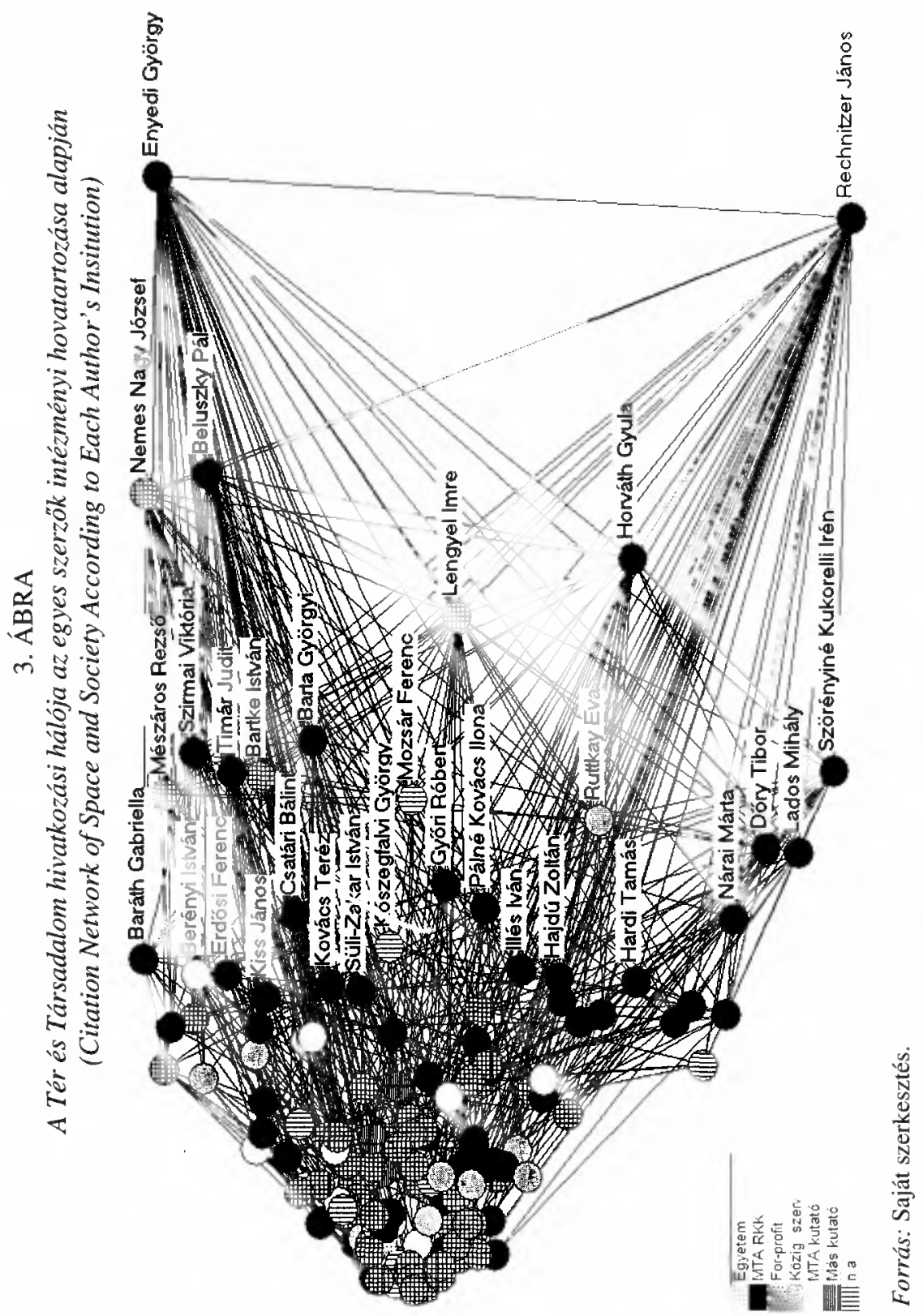


Rechnitzer János : A Tér és Társadalom első húsz éve

Tér és Társadalom 20. évf. 2006/4. 1-13. p.

Amennyiben az adatbázisba bevonjuk az egyes szerzök intézményi hátterét (3. ábra), még egyértelmúbbé válik az MTA Regionális Kutatások Központjának meghatározó, szakma-alakító szerepe. Az intézet vezetó munkatársai jelennek meg a hálózat fontosabb kapcsolati csomópontjain, míg az egyetemi, felsőoktatási szférában dolgozó szerzők gyengébb belsỏ kapcsolatokkal, mérsékeltebb hálózat alakító szereppel rendelkeznek.

Jól látható az MTA Regionális Kutatások Központja kutatóinak a regionális tudományt befolyásoló szerepe, ha az egyes szerzőket jelző pontok nagyságához a Freeman fokszámon alapuló központiság értékét (NrmInDegree) rendeljük, és az elrendezést a geometrikus távolságok alapján rajzoljuk fel (4. ábra).

\section{4. ÁBRA}

A Tér és Társadalom hivatkozási hálója az egyes szerzök intézményi háttere alapján a központiság értékének figyelembevételével

(Citation Network of Space and Society According to the Author's Institution, Considering the Value of Centricity)

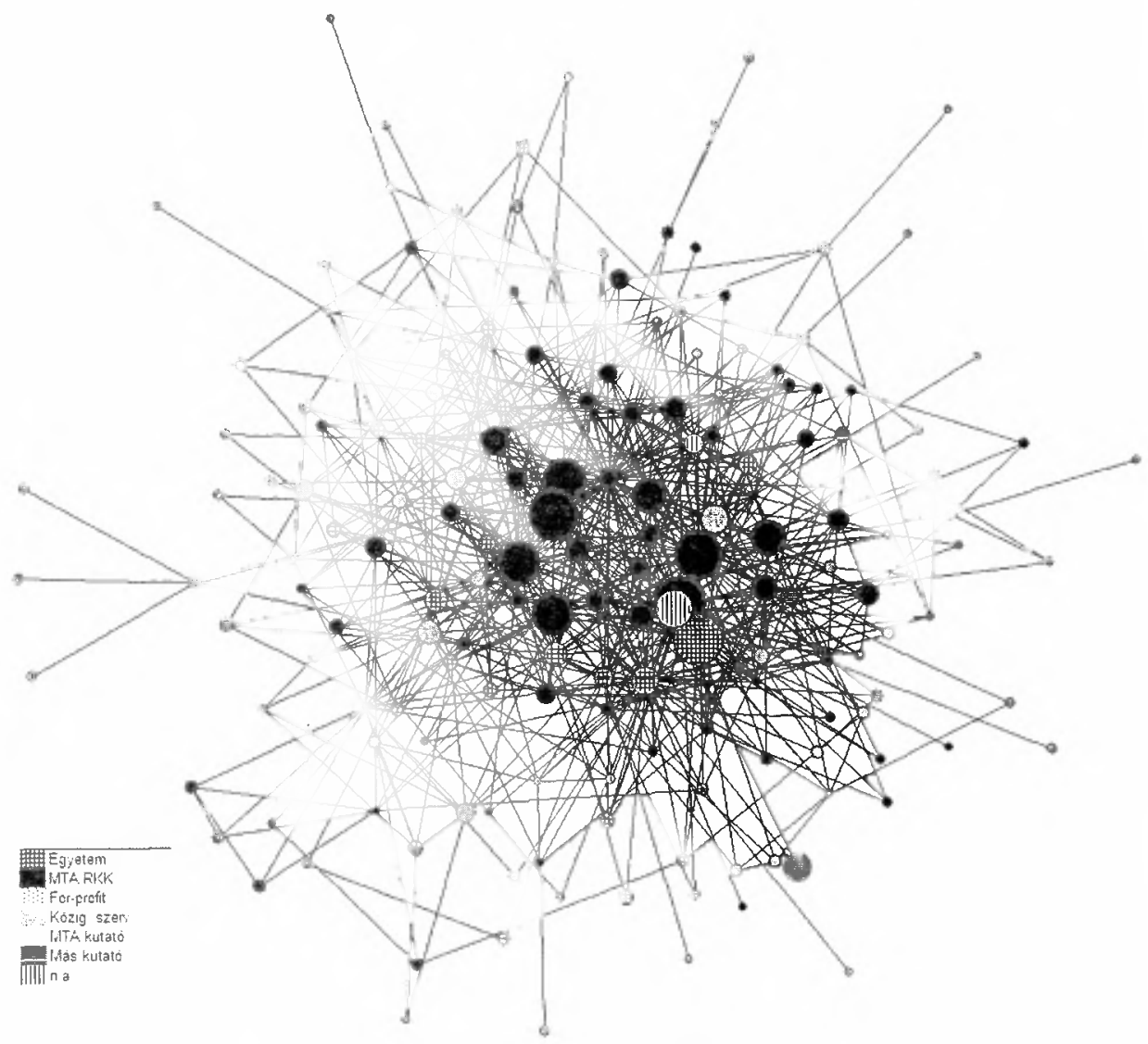

Forrás: Sajăt szerkesztés. 
Igazolható tehát, hogy a Tér és Társadalom meghatározó szerzői az MTA Regionális Kutatások Központjából kerülnek ki. (Minél központibb, meghatározóbb egy szerzö, annál közelebb került az ábra középpontjához.) Ehhez kapcsolódnak azok az egyetemek, ahol a diszciplínával foglalkozó tanszékek, doktori iskolák múködnek és az MTA további kutatóintézetei. A szerzőktỏl kifutó hivatkozások alapján számított háló-központiság (kifok-központiság) ebben az esetben 13\%, míg a szerzőkhöz befutó hivatkozások alapján számított háló-központiság (befok-központiság) 32,7\%, ami az előzőnek két és félszerese. A kifok-kơzpontiság meglehetősen alacsony, ami nem meglepỏ, hiszen a szerzők nagy része sokat hivatkozik kifelé. A befok központiság pedig azt mutatja, hogy bár vannak centrális, meghatározó kutatók, szerzök a hálózatban, de a regionális tudomány, mint szakmai hálózat nem annyira hierarchizált, mint ahogy az elvárható lenne. Ezt támasztja alá a befok átlag és a szórás aránya is (az átlag 5, a szórás 7,74). A szórás egy kicsivel nagyobb csak az átlagnál. Ugyanezen értékek a kifoknál teljesen megegyeznek (átlag 5,00, szórás 5,086).

$\mathrm{Az}$ eredmények alapján megállapíthatjuk, hogy a regionális tudományon belül vannak meghatározó kutatók, szerzók. A szakteruilet fiatal volta (pl. az alapítók generációja szoros kapcsolatot ápol a következó generációkkal) következtêben a tudományos együttmüködés lehetősége nagy, aminek kỏvetkeztében a fiatalabb vagy újabb generáció képviselöi, szerzői is könnyen kaphatnak szakmai figyelmet, azaz esetünkben hivatkozást.

A regionális tudomány hálózati kapcsolatainak kutatása itt nem ért véget, mondhatjuk, most kezdődik el. A hivatkozási háló az újabb Tér és Társadalom számok megjelenésével tovább növekszik, és vélhetően strukturálódik át, így a tudományos színtér, a kapcsolatok is változnak. A regionális tudomány multidiszciplináris jellegéből fakad, hogy más tudományteriuletek nyilvánossága befogadója a Tér és Társadalomban publikált szerzöknek. A vizsgálat érdekességén - s kísérleti jellegén felbuzdulva a jövőben a tudományos nyilvánosság újabb köreinek (más társadalomtudományi folyóiratok) feltérképezésére, s ezzel a regionális tudomány további szakmai befolyásának, kapcsolatainak elemzésére kerülhet sor.

\section{Egy föszerkesztōi korszak feljegyzései}

A Tér és Társadalom fószerkesztői feladatait emlékeim szerint 1994-ben vettem át. Az RKK Igazgató Tanácsán rendszeresen napirend volt a folyóirat megjelenése, amit belső technikai (nyomtatás), szervezési problémák nehezítettek. Az elhúzódás okait most már - nagyobb tapasztalatok birtokában - abban is látom, hogy több tematikus szám szerkesztése történt, s azok összeállítása nem egyszerü feladat. A szerzők elmaradása, lemaradása a tervezett füzetek kiadását késleltetheti. A kilencvenes évek elején a technikai szerkesztés és nyomda sem állt azon a szinten, mint ma, így a csúszások természetesnek tekinthetők, hangsúlyozom a mai tapasztalatokkal és feltételekkel.

Az első időszakban Pfeil Edit volt a szerkesztő, öt számot készítettünk együtt, ezek többsége tematikus szám volt, és lényegében összeállt anyagok voltak. Edit roppant precíz, alapos szerkesztő, gondosan nézte át a kéziratokat, jól kommunikált 
a szerzőkkel. A Pécs-Győr távolság - még nem volt e-mail - nehezen volt leküzdhető, ami szervezési gondokat jelentett, egyeztetési problémákat vetett fel. 1996 elejére Edit gyesre vonult, így nem tudta tovább vállalni a szerkesztést. Győrben egy számot álítottunk össze Telekes Annamáriával, aztán hét szám Nagy Erika bevonásával került szerkesztésre. Konfliktusoktól mentes időszak volt, öt tematikus szám kapcsolódott a közös munkához. Ebböl kettőt emelnék ki. Az egyik a fiatal regionalisták első konferenciảjának anyaga (1996. 2-3. sz.), illetve az ÉszaknyugatDunántúl térségére vonatkozó fejlesztési koncepciót bemutató füzet (1997. 1. sz.). A fiatal regionalisták közül napjainkra már többen érett szakemberek, kutatók, oktatók lettek, így rendszeresen publikálnak a folyóiratban. A térségi fejlesztési koncepciót bemutató szám szakmai újdonságnak számított, mert egy átgondolt és akkor elsöként tesztelt területi tervezési technikát, annak elemeit mutattuk be.

1998 elejétỏ] vette át a Tér és Társadalom szerkesztését a Hardi Tamás-Nárai Márta páros. Akkor még nem rendelkeztek kellö tapasztalattal a szerkesztésben, de aktivitásuk és lelkesedésük révén sikerült leküzdeni az ismeretek hiányának nehéz időszakát és lényegében 1999 végére a számok megjelenésének ritmusa beállt a negyedéves ütemezésbe.

Alapvető érdemének tekintem a Hardi-Nárai szerkesztői párosnak, hogy garantálta a folyamatos megjelenést. A folyóirat szerkesztési színvonala folyamatosan javult. (Birtokomban van egy szám 1998. végéröl, amit a Föigazgató úr ,utószerkesztett”, s észrevételeit pirossal bejelölte. Nos, a tanulságokat leszürtük, s mára a szerkesztői gondosság jellemzi a lapot). A helyzeten az is javított, hogy a technikai szerkesztés feltételei megváltoztak, Kómüves Marika vállalta ezt a nem könnyủ feladatot, de a hardver és szoftver vetületek is korszerüsödtek, így a megjelenés gyorsaságán és föleg a kivitel minőségén is lehetett változtatni. 2000 végétől új arculattal jelenik meg a Tér és Társadalom. Galgóczy György festőmüvész által kidolgozott geometrikus formációt az évszakokhoz, illetve egy kicsit a számok tartalmának hangulatához lehet igazítani, s tükrözi egyben a regionális tudomány frissességét, a problémák eleven feldolgozását.

Arra a kérdésre, hogy milyen szerkesztési koncepciót követtünk az elmúlt 12-13 évben nem könnyủ válaszolni. Mint láttuk, az induláskor, a kilencvenes évek közepén inkább a lap zavartalan múködési feltételeinek megteremtése volt a cél. Közben a szakmai közeg megváltozott. Megjelentek új folyóiratok, így a Comitatus (1991), Falu Város Régió (1994), A Falu (1985), Európai Szemle (1990), Európai Tükör (1999), Pro Minoritate (1996), amelyek fogadták a cikkeket, tanulmányokat, illetve újjászülettek régiek (pl. Területi Statisztika, Alföldi Tanulmányok 1992). Átalakult a tudományos közlések piaca. Számos más diszciplínát képviselö folyóirat egyre nagyobb érdeklődést mutatott a regionális tudomány iránt, így „falta” a tanulmányokat. Korábban egy-egy közlemény megjelentetése nehézségekbe ütközött, hiszen kínálati túlsúly volt, azaz kevés volt a lap, sok a szerző. Ezzel szemben az évtized közepérevégére nött a lapok száma, egyre több konferencia kiadvány jelent meg, tanulmánykötetek láttak napvilágot, monográfiák vagy azok egész sorozata indult útjára. 
Megfordult tehát a helyzet. Úgy 1997-2001 között egy kisebb közlési vákuum alakult ki, amikor nem volt könnyủ jó cikkeket találni. Ez meglátszik a Tér és Társadalom folyóiraton, nőtt a házi szerzők száma, a témák nagyon diverzifikáltak, nem sikerült tematikus számokat szerkeszteni. Megtartottuk az első közlés jogát, s ahhoz keményen ragaszkodtunk, de meg kell vallani, voltak időszakok, amikor a „postás szerkesztette a lapot", azaz vártuk, hogy érkezzen be a szám összeállításához szükséges mennyiségü kézirat. Számokat vontunk össze (szinte minden évben kettös számok voltak), visszatérö, megbízható házi szerzőkre támaszkodtunk (RKK és Nyugatmagyarországi Tudományos Intézet kutatói), konferencia kötetként kezeltük a lapot.

A változások, 2002 körül indultak meg. Ekkorra jelent meg egy új piac, éspedig a doktori hallgatók egyre szélesedỏ tábora. Nem volt haszontalan a fiatal regionalisták konferenciáinak gondozása, mert ez is ösztönözte a legjobbakat, hogy merjék közreadni önálló kutatási eredményeiket. Pécs, Budapest, Szeged, késöbb Miskolc, napjainkra Györ témához kapcsolódó doktori iskoláinak kiváló hallgatói jelentek meg tanulmányokkal. A szakma széles skáláját fogják be, de azért a regionális tudomány divatos irányait jellemzik, így a vidékfejlesztést, a városfejlödés kérdéseit, határ menti kapcsolatokat, a turizmus és idegenforgalmat, a periferizálódást, a területi különbségeket, azok sajátosságait, a közlekedés térségi összefüggéseit.

Érdekes módon miközben a szakma állandóan hangos volt a regionalizációtól, nem, vagy csak néhány tanulmány foglalkozott ezzel a kérdéssel. Hasonlóan elhanyagolták a szerzök (szerkesztök?) a regionális politikát, annak müködésének elemzését, de az elméleti rendszereinek bemutatását is. Nem kapott figyelmet az önkormányzatok müködése, azok hatása a területi folyamatok alakulására, s egyáltalán az önkormányzati rendszer és a regionális fejlödés kapcsolta. Kevés módszertani tanulmány látott napvilágot. Általában nem jellemző a szakmára a briliáns módszertani eszköztár alkalmazása, ennek elméleti megalapozása igen csak hiányos, így a lapban szinte azonnal közöltük az elemzésekben újszerủ eszközöket, technikákat kínáló cikkeket.

Háttérbe szorult a Tér és Társadalom korábbi szerkesztésének azon törekvése, hogy a regionális tudomány nemzetközi szinten haladó szerzőinek alapvető, új elméletet és/vagy módszertant indító tanulmányait magyar nyelven közreadja. Talán két eredményre lehetek büszke föszerkesztői müködésem alatt, az elsö, hogy 2000-ben megjelentettük a szerző engedélyével Krugman előremutató tanulmányát az új gazdaságföldrajz elméletéről (2000. 4. sz.), s a másik, a kritikai földrajzi tematikus szám (2003. 2. sz.), aminek szerkesztésében nagy és meghatározó szerepe volt Tímár Juditnak.

\section{Merre tovább Tér és Társadalom?}

A folyóirat jövőjét vagy a további évek szerkesztési elveit lényegében a fentiek már körvonalazzák. Végre kialakultak a megfelelő szerkesztői infrastruktúra személyi és tárgyi feltételei, a terjesztés rendszere szervezett és pontos, a lap iránt az érdeklỏdés növekszik, a régebbi számok elérhetök (Internet), az arculat nem kíván radikális változást, a lap felépítése áttekinthető és követhetỏ. Egyértelmủen le kell szögezni, hogy biztosított a lap müködéséhez a kézirat állomány, az elméleti cikkek lektorálása megtörténik. 
Az érettség szakaszába jutott folyóirat jövőjének egyik lehetséges iránya, hogy évente egy-egy tematikus szám összeállítása történjen meg. Ezt meg kell tervezni, évekre előre ki kell jelölni a föbb témaköröket, $s$ felkérni a témakörök neves hazai kutatóit a vendégszerkesztésre. A másik irány a publikációs felkérés, egy-egy „,hiányzó” témakörben tanulmányok írásának kezdeményezése, s ezzel a regionális tudomány új kutatási irányainak felvillantása. Átlapozva a Tér és Társadalom korábbi számait főleg Beluszky Pál föszerkesztősége alattiakat - nagyobb nyitottságot, sokszínủséget, nagyobb szellemi szabadságot tapasztaltam a tér, a térbeliség vagy akár a település probléma kezelésében. Az ezredforduló utáni Tér és Társadalom számok erősen szakmai „ízúek” lettek, a szakkérdések dominálnak, vagy a korábban jelzett divatkutatások. A térbeliség összetettebb, árnyaltabb, sokoldalúbb és ezzel sokszínủbb megközelítésére kell ösztönözni a szerzőket, több legyen a tudományos töprengés, a vita, a nézetek ütköztetése, akár ugyan annak a témának többoldalú - azaz más és más tudományos szemléletben történő - feldolgozását kezdeményezzük.

Nem feledkezhet meg a folyóirat a nemzetközi regionális tudomány fontosabb eredményeinek és irányzatainak bemutatásáról sem. Számonként egy-egy elöremutató jelentős külföldi cikket közre kell adni. A Krónika rovatot újra kell éleszteni, ebben elsősorban nem a konferencia dömpingról kell hírt adni, hanem a regionális tudományhoz kapcsolódó tudományos fokozat szerzésröl, s a szakmai fórumok munkájáról. Továbbra is legyen könyvjelző a Tér és Társadalom, azaz a regionális tudományt érintő monográfiák, tanulmánykötetek bemutatása történjen meg, de nem az ismertetés, hanem a kritikai hangsúlyok erősítésével.

A hazai társadalomtudományi folyóiratok között a Tér és Társadalom kivívta magának a megfeleló tekintélyt. Ismert és elismert a folyóirat, már nemcsak a hazai, hanem a magyar nyelvủ regionális tudományi centrumok kutatási eredményeit is közreadja, illetve eljut minden helyre, ahol ezt a szakmát igényesen múvelik, illetve a gyakorlatban éppen a tudományos eredmények figyelembe vételével végzik, müködtetik. A két évtized a tudomány történetében egy kis momentum, egy új tudomány megteremtésében viszont a kemény, a dolgos évek koncentrátuma. A Tér és Társadalom hozzásegítette a regionális tudományt, hogy elfogadott és elismert legyen, de egyben a jövőjének is egyik záloga.

Köszönöm a Tér és Társadalom korábbi föszerkesztőinek, szerkesztőinek alkotó munkáját, tisztelettel adózunk szerzőinknek és várjuk további müveiket. Üdvözöljük olvasóinkat, kérve őket, hogy ne csak olvassák és terjesszék a folyóiratot, hanem véleményükkel is lássanak el bennünket, hogy a megújításunk - a következó évtizedek - a befogadók igényét is tükrözzék. 


\section{Jegyzetek}

' A jelen fejezet Reisinger Adrienn és Tóth Péter doktorandusz hallgatók elemzése alapján került összeállításra.

${ }^{2}$ Itt jegyeznénk meg, hogy a hivatkozási szabályok rossz használata szintén adatveszlést okozott, pl. a szerkesztett tanulmánykötetben közreadott írásmü esetén sok esetben csak a szerkesztett müre történỏ hivatkozás történt meg, így a szerzők nem voltak beazonosíthatók.

${ }^{3}$ A számításokat és a grafikonokat az Ucinet és Pajek programokkal végeztük.

${ }^{4}$ A tudományos karrier szempontjából a hivatkozás az egyik fontos fokmérö, ezért az egymáshoz emberileg is közel álló kutatók segíthetik egymás elömenetelét. Sok esetben a személyes szimpátia avagy antiszimpátia is befolyásolja egy tanulmányban a meghivatkozott szerzöket, illetve azok müveit.

${ }^{5}$ Érdekes lenne azonban megvizsgálni a Têr és Társadalom létezése elött megjelent tanulmányainak hivatkozásait is, amiböl a komplett tudományos pálya íve felállítható. 